\title{
ANTECEDENT TERHADAP KEPATUHAN WAJIB PAJAK BADAN DENGAN TAX AMNESTY SEBAGAI PEMODERASI
}

\author{
Ayu Komala Dewi, Syahril Djadang, dan Darmansyah \\ Magister Akuntansi Universitas Pancasila \\ E-mail: Ayudewi.consultant@gmail.com
}

\begin{abstract}
This study aims to identify and analyze the impact of tax audit and enforcement of compliance on corporate tax payers, with the tax amnesty as a moderating factor. The study population was registered corporate tax payers in KPP Pratama Depok. This research is using random sampling method with a total of 100 respondents. Data analysis was performed using Moderate Regression Analyst (MRA), which contains elements of interaction (multiplication of two or more independent multiplication) by using SPSS 22 for windows. The study used a questionnaire statement that is processed with statistical test. The results showed that the tax audit, law enforcement if it is moderated by tax amnesty has positively significant impact on tax compliance entities.
\end{abstract}

Keywords: Tax Audit, Enforcement, Tax Amnesty, Tax Payer Compliance

\section{PENDAHULUAN}

Penyebab rendahnya rasio penerimaan pajak negara (tax ratio) adalah masih rendahnya kepatuhan penyampaian perpajakan (tax compliance). Peran serta dan partisipasi Warga Negara Indonesia (WNI) untuk membangun negara salah satunya dengan membayar pajak. "Dalam beberapa tahun terakhir penerimaan pajak masih rendah. Bukan saja penerimaan nasional yang belum optimal, rasio pajak juga mengalami penurunan," ungkap Menteri Keuangan Sri Mulyani.

Tabel 1. Tingkat Kepatuhan Wajib Pajak Badan.

\begin{tabular}{|l|l|l|l|l|}
\hline Tahun & $\begin{array}{c}\text { Wajib Pajak } \\
\text { Badan Terdaftar }\end{array}$ & $\begin{array}{c}\text { Wajib Pajak Badan } \\
\text { Yang wajib } \\
\text { melaaporkan SPT }\end{array}$ & $\begin{array}{c}\text { Wajib Pajak Badan yang } \\
\text { menyampaikan SPT } \\
\text { Tahunan PPh }\end{array}$ & \multicolumn{1}{|c|}{ Rasio Kepatuhan } \\
\hline 2015 & 2.472 .632 & 1.184 .816 & 681.331 & $58.00 \%$ \\
\hline 2014 & 2.322 .686 & 1.166 .036 & 552.714 & $47,40 \%$ \\
\hline 2013 & 2.116 .049 & 1.141 .797 & 546.346 & $47.85 \%$ \\
\hline 2012 & 1.898 .547 & 1.026 .388 & 497.131 & $48,43 \%$ \\
\hline 2011 & 1.760 .108 & 1.590 .154 & 431.022 & $27,11 \%$ \\
\hline
\end{tabular}

Sumber : Laporan Tahunan 2015 Dirjen Pajak

Dapat dilihat rasio tingkat kepatuhan wajib pajak badan dari tahun 2011-2014 masih sangat rendah dengan rasio rata-rata 42,69\%, namun pada tahun 2015 terdapat kenaikan rasio yaitu menjadi $58 \%$. BPS mencatat hingga tahun 2013 perusahaan yang sudah beroperasi sebanyak 3.442.307, artinya belum semua perusahaan terdaftar sebagai wajib pajak badan.

Ikhsan (2007) menyatakan bahwa peran serta masyarakat wajib pajak dalam memenuhi kewajiban pembayaran pajak JIAFE (Jurnal Ilmiah Akuntansi Fakultas Ekonomi) Volume 3 No. 1 Tahun 2017, Hal. 49-61 
berdasarkan ketentuan perpajakan sangat diharapkan, agar kepatuhan wajib pajak dalam membayar pajak meningkat dan hal ini merupakan posisi strategis dalam peningkatan penerimaan pajak.

Rahayu (2009) menyatakan pemeriksaan dan penyelidikan pajak merupakan salah satu upaya pemerintah untuk membentuk perilaku kepatuhan Wajib Pajak (WP) orang pribadi maupun suatu badan usaha. Kepatuhan Wajib Pajak adalah kemauan dan kesadaran Wajib Pajak untuk memenuhi segala kewajiban perpajakannya. Pemerintah tentu mengharapkan agar modernisasi yang berjalan ini mampu meningkatkan kepatuhan Wajib Pajak. Karena dengan adanya peningkatan kepatuhan Wajib Pajak maka penerimaan negara dari sektor pajak juga meningkat pula.

Penegakan hukum kepada Wajib Pajak yang tidak patuh, yaitu mereka yang tidak menanggapi pemberitahuan/himbauan untuk mendaftarkan diri sebagai WP dan atau tidak melaporkan pajaknya sesuai dengan ketentuan yang berlaku tersebut, antara lain adalah dengan melakukan pemeriksaan pajak terhadap Wajib Pajak tersebut. Selanjutnya apabila penghasilan Wajib Pajak telah melampaui penghasilan tidak kena pajak (untuk WP perseorangan), atau setelah satu bulan saat usaha dijalankan, WP badan tidak mendaftarkan dirinya untuk memperoleh NPWP, maka dapat diberikan Nomor Pokok Wajib Pajak (NPWP) secara jabatan, atau dilakukan penyidikan.

Di samping itu, dalam Pasal 39 ayat (1) Undang-undang Nomor 6 tahun 1983 tentang Ketentuan Umum Dan Tata Cara Perpajakan sebagaimana telah diubah dengan Undang-undang Nomor 28 tahun 2007 (UU No. 28/2007), kepada mereka juga dapat dikenai sanksi pidana dengan ancaman penjara paling lama enam tahun dan denda paling tinggi empat kali jumlah pajak yang terhutang yang tidak atau kurang dibayar.
Presiden Joko Widodo telah
menandatangani Undang-Undang Nomor 11 Tahun 2016 tentang Pengampunan Pajak atau UU Tax Amnesty pada 1 Juli 2016. Di masa awal penerapan pengampunan pajak ini, ada ketertarikan dan atensi yang cukup baik di kalangan pengusaha dan wajib pajak sehingga diharapkan tingkat kepatuhan pajak meningkat signifikan. Program Tax Amnesty ini harus disukseskan karena tujuannya hanya satu, yaitu tersedianya pendanaan pembangunan Indonesia secara berkelanjutan.

UU Tax Amnesty ini adalah bagian dari reformasi pajak secara menyeluruh di Indonesia. UU Tax Amnesty merupakan starting point yang nantinya akan diikuti dengan amandemen UU pajak yang lain seperti RUU KUP (Ketentuan Umum dan Tata Cara Perpajakan), RUU PPh, RUU PPN dan RUU Bea Materai. Keseluruhan paket regulasi itu diharapkan berimplikasi pada naiknya pendapatan negara dari sektor perpajakan.

Tujuan penelitian ini Untuk menguji pengaruh pemeriksaan pajak, penegakan hukum terhadap tingkat kepatuhan wajib pajak badan yang terdaftar di KPP Depok ketika dimoderasi oleh tax amnesty.

\section{KAJIAN LITERATUR}

Jatmiko (2006) menjelaskan bahwa teori pembelajaran sosial ini relevan untuk menjelaskan perilaku wajib pajak dalam memenuhi kewajibannya membayar pajak. Seseorang akan taat membayar pajak tepat pada waktunya, jika lewat pengamatan dan pengalaman langsungnya, hasil pungutan pajak itu telah memberikan kontribusi nyata pada pembangunan di wilayahnya. Seseorang juga akan taat pajak apabila telah menaruh perhatian terhadap pelayanan pajak, baik fiskus maupun sistem pelayanan pajaknya. Terkait dengan proses penguatan, dimana individu-individu disediakan rangsangan positif atau ganjaran supaya berperilaku sesuai dengan model, tampaknya cukup relevan apabila dihubungkan dengan 
pengaruh sanksi pajak terhadap kepatuhan pajak.

Beberapa peneliti kepatuhan pajak menggunakan konsep theory of planned behavior (Ajzen, 1991) untuk menjelaskan perilaku kepatuhan pajak wajib pajak. Berdasarkan teori ini, perilaku individu untuk tidak atau patuh terhadap ketentuan perpajakan dipengaruhi oleh niat berperilaku dan niat berperilaku tidak atau patuh dipengaruhi oleh tiga factor, yaitu: 1) behavioral belief yaitu keyakinan akan hasil dari suatu perilaku (outcome belief) yang membentuk variabel sikap (attitude), 2) normative belief yaitu keyakinan individu terhadap harapan normatif yang menjadi rujukannya yang membentuk variabel normatif subjektif (subjective norm), dan 3) control belief yaitu keyakinan/persepsi individu tentang keberadaan hal-hal yang mempengaruhi (menghambat atau mendukung) perilaku yang membentuk variabel kontrol perilaku yang dipersepsikan (perceived behavioral control).

Penyebab wajib pajak tidak patuh bervariasi dan penyebab utama adalah penghasilan yang diperoleh wajib pajak yang utama ditujukan untuk memenuhi kebutuhan hidupnya. Timbulnya konflik antara kepentingan diri sendiri dan kepentingan negara. Sebab lain adalah wajib pajak kurang sadar tentang kewajiban bernegara, tidak patuh pada aturan, kurang menghargai hukum, tingginya tarif pajak, dan kondisi lingkungan sekitar (Jatmiko, 2006).

Pemeriksaan pajak telah diatur dalam pasal 1 angka 25 UU Nomor 6 Tahun 1983 tentang Ketentuan Umum dan Tata Cara Perpajakan sebagaimana telah diubah terakhir dengan UU Nomor 16 Tahun 2009 yang menyatakan bahwa: "Pemeriksaan adalah serangkaian kegiatan untuk menghimpun dan mengolah data, keterangan dan atau bukti yang dilaksanakan secara objektif dan profesional berdasarkan suatu standar pemeriksaan untuk menguji kepatuhan pemenuhan kewajiban perpajakan dan atau untuk tujuan lain dalam rangka melaksanakan ketentuan perundangundangan perpajakan".

Peraturan yang dibuat harus ditegakkan agar dapat tercapai tujuan dibuatnya peraturan tersebut. Peraturan mengenai penagihan pajak yang telah ditetapkan pemerintah juga harus ditegakkan agar tercapai tujuannya, yakni "untuk memberikan kepastian hukum dan keadilan serta mendorong peningkatan kesadaran dan kepatuhan masyarakat dalam memenuhi kewajiban perpajakannya" (sebagaimana tercantum di dalam bagian Menimbang UU Nomor 19 Tahun 2000 tentang Perubahan Atas Undang-Undang Nomor 19 Tahun 1997 tentang Penagihan Pajak Dengan Surat Paksa).

Kepatuhan wajib pajak dapat dilihat dari seberapa besar penerimaan pajak, penerimaan pajak menggambarkan peran serta rakyat untuk mengambil peranan dalam pembangunan negara dan membiayai pemerintahan. Semakin tinggi penerimaan dari sektor pajak maka semakin patuh wajib pajak dalam melaksanakan kewajiban perpajakannya. 


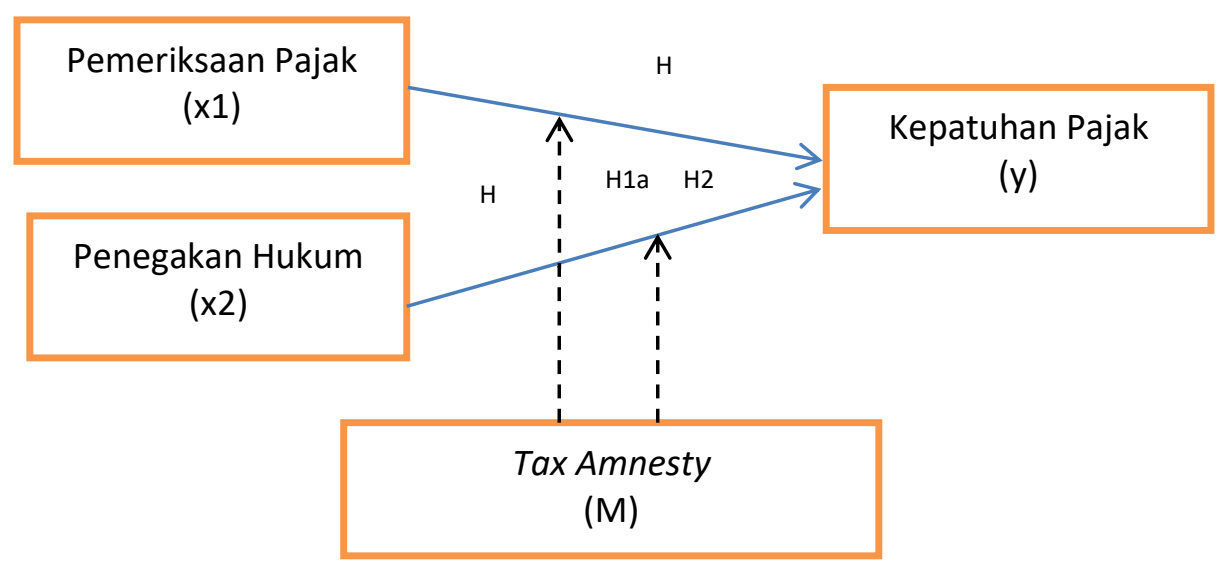

Gambar 1. Kerangka Pemikiran Empiris

\section{PENGEMBANGAN HIPOTESIS}

Pengaruh Pemeriksaan Pajak Terhadap Kapatuhan Wajib Pajak Badan

Mandagi, Sabiano, Tirayoh (2014) menganalisis pengaruh pemeriksaan pajak terhadap tingkat kepatuhan Wajib Pajak badan dalam memenuhi kewajiban perpajakannya pada Kantor Pelayanan Pajak (KPP) Pratama Manado. Berdasarkan hasil penghitungan nilai rata-rata dari responden pemeriksa pajak pada KPP Pratama Manado, untuk kriteria pemeriksaan pajak termasuk dalam kriteria sangat memadai, sedangkan untuk kriteria kepatuhan Wajib Pajak badan termasuk dalam kriteria patuh. Dari hasil penelitian diketahui bahwa pemeriksaan pajak berpengaruh terhadap tingkat kepatuhan Wajib Pajak badan pada Kantor Pelayanan Pajak Pratama Manado. Berdasarkan hal tersebut maka dirumuskan hipotesis sebagai berikut:

H1: Pemeriksaan pajak berpengaruh positif terhadap kepatuhan wajib pajak badan.

H1a: Pemeriksaan pajak berpengaruh positif terhadap kepatuhan wajib pajak badan ketika dimoderasi dengan kebijakan tax amnesty.
Pengaruh Penegakan Hukum terhadap Kapatuhan Wajib Pajak Badan

Indonesia menganut sistem self assessment dalam perhitungan pajak, self assessment tersebut membuka peluang kecurangan-kecurangan oleh para Wajib Pajak dalam memenuhi kewajiban perpajakannya. Peraturan mengenai penagihan pajak yang telah ditetapkan pemerintah juga harus ditegakkan agar tercapai tujuannya, yakni "untuk memberikan kepastian hukum dan keadilan serta mendorong peningkatan kesadaran dan kepatuhan masyarakat dalam memenuhi kewajiban perpajakannya" (sebagaimana tercantum di dalam bagian menimbang UU Nomor 19 Tahun 2000 tentang Perubahan Atas Undang-Undang Nomor 19 Tahun 1997 tentang Penagihan Pajak Dengan Surat Paksa).

Jurnal yang ditulis Modugu dan Anyaduba (2014) bertujuan menjelaskan pengaruh tax audit, penalty/law enforement, government spending and change of government policy pada tingkat kepatuhan pajak di perusahaan-perusahaan di Nigeria. Hasil analisis menunjukkan bahwa kemungkinan di audit, persepsi atas pengeluaran pemerintah, hukuman dan penegakan hukum/aturan, pengaruh bersama tax audit dan penalti, memiliki tendensi untuk secara signifikan 
memengaruhi kepatuhan pajak di Nigeria. Hal tersebut dirumuskan sebagai berikut:

H2 : Penegakan hukum berpengaruh positif terhadap kepatuhan wajib pajak badan.

H2a: Penegakan hukum berpengaruh positif terhadap kepatuhan wajib pajak badan ketika di moderasi oleh tax amnesty.

\section{METODELOGI PENELITIAN}

Populasi dalam penelitian ini adalah wajib pajak badan yang berdomisili di Depok, dengan asumsi kuesioner yang didistribusikan akan diisi oleh pemilik perusahaan atau karyawan yang mengerti perpajakan atau konsultan pajak perusahaan tersebut. Tehnik pengambilan sampel dilakukan dengan cara probability sampling, teknik pengambilan sampel yang memberikan peluang yang sama bagi setiap anggota populasi. Populasi bersifat homogen maka sampel diambil dengan tehnik random sampling.

Penyampaian kuesioner dilakukan antara bulan Januari - Februari 2017. Masing - masing responden mendapat tiga set kuesioner terdiri dari satu set data responden dan dua set data yang berisi pertanyaan. Setiap variabel terdiri dari 5 pertanyaan.

Tabel 2. Profil Responden Penelitian

\begin{tabular}{|l|l|l|l|}
\hline \multicolumn{1}{|c|}{ Profil Responden } & \multicolumn{1}{c|}{ Kategori } & \multicolumn{1}{c|}{ Frekuensi } & \multicolumn{1}{c|}{ Presentase } \\
\hline \multirow{4}{*}{ Jenis Kelamin } & Laki-laki & 49 & $49 \%$ \\
\cline { 2 - 4 } & Perempuan & 51 & $51 \%$ \\
\cline { 2 - 4 } & Total & $\mathbf{1 0 0}$ & $\mathbf{1 0 0 \%}$ \\
\hline \multirow{4}{*}{ Usia } & $<25$ Tahun & 2 & $2 \%$ \\
\cline { 2 - 4 } & $25-35$ Tahun & 74 & $74 \%$ \\
\cline { 2 - 4 } & $>35$ Tahun & 24 & $24 \%$ \\
\cline { 2 - 4 } & Total & $\mathbf{1 0 0}$ & $\mathbf{1 0 0 \%}$ \\
\hline \multirow{5}{*}{ Latar Belakang Pendidikan } & SMA & 35 & $35 \%$ \\
\cline { 2 - 4 } & Diploma & 27 & $27 \%$ \\
\cline { 2 - 4 } & S1 & 34 & $34 \%$ \\
\cline { 2 - 4 } & S2 & 4 & $\mathbf{1 0 0 \%}$ \\
\cline { 2 - 4 } & Total & $\mathbf{1 0 0}$ & \\
\hline
\end{tabular}

Sumber data : Hasil pengolahan data 2

Metode analisis data yang digunakan dalam penelitian ini adalah Moderate Regression Analysis (MRA) antara kepatuhan pajak sebagai variable endogen, dan variabel eksogennya, yaitu pemeriksaan pajak dan penegakan hukum pajak dengan pemoderasi perubahan kebijakan pemerintah (tax amnesty).

\section{HASIL PENELITIAN Statistik Deskriptif}

Analisis deskriptif dari masing-masing variabel dalam penelitian ini adalah sebagai berikut: 
Table 3. Statistik Deskiptif

\begin{tabular}{|l|r|r|r|r|r|}
\hline & N & Minimum & Maximum & Mean & $\begin{array}{c}\text { Std. } \\
\text { Deviation }\end{array}$ \\
\hline Pemeriksaan pajak (X1) & 100 & 11 & 25 & 20.20 & 3.545 \\
Penegakan hukum pajak (X2) & 100 & 10 & 24 & 19.94 & 3.308 \\
Tax amnesty (M) & 100 & 13 & 25 & 20.11 & 3.210 \\
Kepatuhan wajib pajak (Y) & 100 & 13 & 24 & 20.52 & 3.474 \\
X1.M & 100 & 156 & 600 & 415.64 & 121.780 \\
X2.M & 100 & 140 & 600 & 409.74 & 116.598 \\
Valid N (listwise) & 100 & & & & \\
\hline
\end{tabular}

Sumber data : Hasil pengolahan data dari 2017

Berdasarkan tabel tersebut dapat dilihat nilai minimum, maximum, mean, dan standar deviasi masing-masing variabel sebagai berikut:

1. Dilihat dari variabel pemeriksaan pajak menjelaskan dari 100 perusahaan, terdapat paling sedikit 11 perusahaan dan paling banyak 25 perusahaan dan ratarata 20 perusahaan yang memahami pemeriksaan pajak, sedangkan empat perusahaan lainnya ragu-ragu.

2. Dilihat dari variabel penegakan hukum menjelaskan dari 100 perusahaan, terdapat paling sedikit 10 perusahaan dan paling banyak 24 perusahaan dan ratarata 20 perusahaan yang memahami hukum pajak.

3. Dilihat dari variabel tax amnesty menjelaskan dari 100 perusahaan, terdapat paling sedikit 13 perusahaan dan paling banyak 25 perusahaan dan ratarata 20 perusahaan yang sudah memahami tax amnesty 4.

4. Dilihat dari variabel kepatuhan wajib pajak menjelaskan dari 100 perusahaan, terdapat paling sedikit 13 perusahaan dan paling banyak 24 perusahaan dan ratarata 21 perusahaan yang sudah patuh, sedangkan tiga perusahaan lainnya raguragu.

5. Dilihat dari variabel pemeriksaan pajak ketika dimoderasi oleh tax amnesty menjelaskan dari 100 perusahaan, terdapat paling sedikit 11 perusahaan yang memahami pemeriksaan pajak dan yang merngikuti tax amnesty minimal 13 perusahaan sedangkan paling banyak 25 perusahaan dari yang memahami pemeriksaan pajak dan 25 perusahaan tersebut mengikuti tax amnesty dengan rata-rata 21 perusahaan yang memahami dan mengikuti tax amnesty, sedangkan empat perusahaan lainnya ragu-ragu.

6. Dilihat dari variabel penegakan hukum pajak ketika dimoderasi oleh tax amnesty menjelaskan dari 100 perusahaan, terdapat paling sedikit 10 perusahaan yang memahami penegakan hukum dan yang merngikuti tax amnesty minimal 13 perusahaan sedangkan paling banyak 24 perusahaan dari yang memahami penegakan hukum dan 25 perusahaan tersebut mengikuti tax amnesty dengan rata-rata 21 perusahaan yang memahami dan mengikuti tax amnesty, sedangkan tiga perusahaan lainnya ragu-ragu.

\section{Validitas dan Reliabilitas}

Semua item nilai korelasi lebih dari $r$ tabel 0,19. Dengan ini maka dapat disimpulkan bahwa item-item kuesioner tersebut valid. Nilai cronbach alpha pada uji validitas untuk ke empat variabel di atas 0,600 . Karena nilai tersebut lebih besar dari 
0,600 maka alat ukur kuesioner reliabel atau telah memenuhi syarat reliabilitas.

\section{Uji Asumsi Klasik}

Pada uji normalitas dapat diketahui bahwa nilai signifikansi (Asym.sig 2 tailed) sebesar 0,520. Karena nilai lebih dari 0,05, jadi residual terdistribusi normal. Hasil uji mulitikolinearitas dapat diketahui bahwa nilai VIF lebih dari 10,00 dan tolerance kurang dari 0,100 untuk ke empat variabel, maka dapat disimpulkan bahwa model regresi terjadi multikolinearitas, maka penulis melakukan uji multikolinearitas Ln. disimpulkan bahwa setelah dilakukan uji multikolinearitas Ln nilainya VIF $>10$, dan tetap terjadi multikolinearitas pada variabel-variabel yang diuji. Penggunaan dari regresi metode MRA yang menimbulkan terjadinya multikolinearitas disebabkan adanya kelemahan yaitu variabel interaksi yang didapat dari perkalian variabel independen dengan variabel moderasi. Dapat diketahui bahwa keempat variabel nilai signifikansi lebih dari 0,05 (tidak signifikan). Jadi dapat disimpulkan pada model regresi tidak ada masalah heteroskedastisitas.

\section{Analisis Regresi Metode MRA (Moderate Regression Analysis) \\ $\left.Y=4,027+1,198 X_{1}-0,566 X_{2}-0,040\right) X_{1} M+$ $0,049 \mathrm{X}_{2} \mathrm{M}$}

Variabel yang berpengaruh signifikan yaitu nilai Sig $<0,05$. Konstanta sebesar 4,027 artinya jika pemeriksaan pajak, penegakan hukum pajak, X1.M dan X2.M nilainya adalah 0 , maka kepatuhan wajib pajak (Y) nilainya sebesar 4,027. Koefisien regresi variabel pemeriksaan pajak $\left(X_{1}\right)$ sebesar 1,198 artinya setiap peningkatan pemeriksaan pajak sebesar 1 satuan, maka akan meningkatkan kepatuhan wajib pajak sebesar 1,198 satuan, dengan asumsi variabel independen lain nilainya tetap. Dan koefisien regresi variabel interaksi antara penegakan hukum pajak dengan tax amnesty $\left(\mathrm{X}_{1} \mathrm{M}\right)$ sebesar 0,049 yang artinya setiap peningkatan interaksi antara penegakan hukum pajak dengan tax amnesty sebesar 1 satuan, maka akan meningkatkan kepatuhan wajib pajak sebesar 0,049 satuan, dengan asumsi variabel independen lain nilainya tetap.

\section{Hasil Uji F}

Tabel 4. Hasil Uji F

ANOVA $^{\text {b }}$

\begin{tabular}{|ll|r|r|r|r|l|}
\hline \multicolumn{1}{|l|}{} & \multicolumn{1}{|c|}{$\begin{array}{c}\text { Sum of } \\
\text { Squares }\end{array}$} & Df & Mean Square & F & \multicolumn{1}{c|}{ Sig. } \\
\hline 1 & Regressio & 2.874 & 4 & .719 & 118.49 & 2 \\
$\mathrm{n}$ & .576 & 95 & .006 & & \\
Residual & 3.450 & 99 & & & \\
\hline
\end{tabular}

a. Predictors: (Constant), LnX2.LnM, Pemeriksaan pajak (LnX1), Penegakan hukum pajak $(\operatorname{Ln} X 2)$, LnX1.LnM

b. Dependent Variable: Kepatuhan wajib pajak (LnY)

Uji $F$ digunakan untuk menguji signifikansi dampak pemeriksaan pajak, penegakan hukum terhadap kepatuhan wajib pajak badan. Untuk menilai signifikansi variabel tersebut dapat dilihat dari nilai $\mathrm{F}$ hasil statistik, apabila nilai signifikansi $\mathrm{F}<$
0,05 maka dapat dikatakan pengujian tersebut signifikan. Dalam penelitian ini nilai F statistik adalah sebesar 0,000 dapat terlihat pada tabel 4.11, oleh karena itu dapat dikatakan dampak pemeriksaan pajak, penegakan hukum dalam penelitian ini 
berpengaruh signifikan terhadap wajib pajak badan.

Hasil Uji t

Tabel 5. Hasil Uji t

Coefficients $^{\mathrm{a}}$

\begin{tabular}{|c|c|c|c|c|c|c|}
\hline \multirow{2}{*}{\multicolumn{2}{|c|}{ Model }} & \multicolumn{2}{|c|}{$\begin{array}{c}\text { Unstandardized } \\
\text { Coefficients }\end{array}$} & \multirow{2}{*}{\begin{tabular}{|c|}
$\begin{array}{c}\text { Standardize } \\
\mathrm{d} \\
\text { Coefficients }\end{array}$ \\
Beta \\
\end{tabular}} & \multirow[b]{2}{*}{$\mathrm{t}$} & \multirow[b]{2}{*}{ Sig. } \\
\hline & & B & Std. Error & & & \\
\hline \multirow[t]{5}{*}{1} & (Constant) & .878 & .256 & & 3.436 & .001 \\
\hline & $\begin{array}{l}\text { Pemeriksaan } \\
\text { pajak (LnX1) }\end{array}$ & 2.578 & 1.120 & 2.696 & 2.302 & .023 \\
\hline & $\begin{array}{l}\text { Penegakan } \\
\text { hukum pajak } \\
(\operatorname{LnX} 2)\end{array}$ & -2.143 & 1.108 & -2.128 & -1.934 & .056 \\
\hline & LnX1.LnM & -.756 & .385 & -4.157 & -1.962 & .053 \\
\hline & $\operatorname{LnX2.\operatorname {LnM}}$ & .849 & .384 & 4.524 & 2.210 & .029 \\
\hline
\end{tabular}

a. Dependent Variable: Kepatuhan wajib pajak (LnY)

Pengujian dalam penelitian ini menggunakan tingkat signifikansi 0,10. Berikut hasil pengujiannya:

1. Variabel pemeriksaan pajak berpengaruh terhadap kepatuhan wajib pajak dengan nilai signifikansi dilihat dari tabel 5 yaitu 0,023 atau $2,3 \%<10 \%$, artinya pemeriksaan pajak berpengaruh positif dan signifikan terhadap kepatuhan wajib pajak badan.

2. Variabel penegakan hukum berpengaruh terhadap kepatuhan wajib pajak nilai signifikansi dilihat dari tabel 5 yaitu 0,056 atau $5,6 \%>10 \%$, artinya pemeriksaan pajak berpengaruh positif signifikan terhadap kepatuhan wajib pajak badan.

3. Variabel pemeriksaan pajak berpengaruh terhadap kepatuhan wajib pajak jika dimoderasi dengan tax amnesty nilai signifikansi dilhat dari tabel 5 yaitu 0,053 atau $5,3 \%>10 \%$, artinya pemeriksaan pajak berpengaruh positif terhadap kepatuhan wajib pajak ketika dimoderasi dengan tax amnesty.

4. Variabel penegakan hukum berpengaruh terhadap kepatuhan wajib pajak jika dimoderasi dengan tax amnesty nilai signifikansi dilihat dari tabel 5 yaitu 0,029 atau $2,9 \%<10 \%$, artinya penegakan hukum berpengaruh positif dan signifikan terhadap kepatuhan wajib pajak jika dimoderasi dengan tax amnesty.

\section{Hasil Uji Koefisien Determinasi (R2)}

$\mathrm{R}^{2}$ berkisar antara 0 sampai 1 , artinya semakin besar nilai $R^{2}$ maka semakin besar variasi variabel endogen yang dapat dijelaskan oleh varibel eksogen. $R^{2}$ dalam penelitian ini dapat dilihat pada tabel di bawah ini: 
Tabel 6. Korelasi dan Determinasi Model Summary ${ }^{b}$

\begin{tabular}{|l|r|r|r|r|r|}
\hline Model & $\mathrm{R}$ & R Square & \multicolumn{1}{c|}{$\begin{array}{c}\text { Adjusted R } \\
\text { Square }\end{array}$} & $\begin{array}{c}\text { Std. Error of the } \\
\text { Estimate }\end{array}$ & Durbin-Watson \\
\hline 1 & $.913^{\mathrm{a}}$ & .833 & .826 & .07787 & 2.007 \\
\hline
\end{tabular}

a. Predictors: (Constant), LnX2.LnM, Pemeriksaan pajak (LnX1), Penegakan hukum

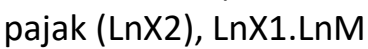

b. Dependent Variable: Kepatuhan wajib pajak (LnY)

Dari pengujian hipotesis diketahui nilai R sebesar 0,826 artinya korelasi (hubungan) antara pemeriksaan pajak dan penegakan hukum dapat menjelaskan variabel kepatuhan wajib pajak yang dimoderasi oleh tax amnesty. Nilai $R$ square sebesar 0,826 yang berarti bahwa sebesar $83 \%$ variabel dependen yaitu kepatuhan wajib pajak dipengaruhi pemeriksaan pajak dan penegakan hukum yang dimoderasi oleh tax amnesty. Sedangkan sisanya (17\%) dipengaruhi oleh variabel lain atau dijelaskan oleh variabel lain yang tidak dimasukkan dalam model penelitian.

\section{PEMBAHASAN}

\section{Pemeriksaan Pajak Berpengaruh terhadap} Kepatuhan Wajib Pajak

Hasil penelitian ini menunjukkan bahwa pemeriksaan pajak berpengaruh dan signifikan terhadap kepatuhan wajib pajak, artinya setiap wajib pajak yang dilakukan pemeriksaan pajak akan berdampak pada kepatuhan wajib pajak. Semakin banyak wajib pajak yang diperiksa maka tingkat kepatuhan wajib pajak akan meningkat.

Hasil penelitian ini konsisten dengan penelitian sebelumnya yaitu Mandagi (2014) yang menunjukkan pemeriksaan pajak berpengaruh positif terhadap kepatuhan wajib pajak. Dalam penelitian tersebut dikatakan tingkat kepatuhan wajib pajak badan yang terdapat di KPP Pratama Manado sebagian besar dipengaruhi oleh pemeriksaan pajak.

Hal ini disebabkan dengan adanya pemeriksaan pajak wajib pajak secara langsung atau dimoderasi akan terdorong untuk meminimalisasi kesalahan baik secara pembukuan atau pun pelaporan pajak. Pada umumnya wajib pajak yang pernah dilakukan pemeriksaan pajak mengalami trauma. Berdasarkan wawancara penulis dengan pemilik perusahaan PT. Miftah Putra Mandiri yang bergerak di bidang developer, Bapak Miftah Sunandar selaku pemilik mengungkapkan:

"Pada saat diperiksa kami semua panik dan kami sedikit trauma. Bagi kami pemeriksaan pajak seperti mimpi buruk. Mau tidak mau kami harus membongkar pembukuan kami beberapa tahun ke belakang dan itu sangat menyita waktu kami. Dampak dari pemeriksaan maka terjadi SKKB (surat ketetapan kurang bayar) akibat dari kelalaian kami yang beberapa kali telat lapor dan telat bayar. Dari semua itu kami mengambil pelajaran untuk selalu tepat waktu baik dalam pelaporan maupun pembayaran."

Akibat dari pemeriksaan pajak akan membuat wajib pajak lebih patuh dan peduli atas laporan maupun pembayaran pajak, dan melakukan pembukuan secara benar serta mengarsip setiap dokumen atas transaksitransaksi tersebut sampai masa daluwarsa pajak yaitu selama 5 (lima) tahun.

\section{Penegakan Hukum Berpengaruh terhadap} Kepatuhan Wajib Pajak.

Berdasarkan data penelitian menunjukkan penegakan hukum 
berpengaruh positif terhadap kepatuhan wajib pajak. Tahun pembinaan pajak telah berlalu, 2016 DJP menetapkan sebagai tahun penegakan hukum. Salah satu upaya DJP untuk meningkatkan penegakan hukum dengan membentuk satgas khusus untuk pemberantasan tindak pidana pajak.

Hal ini merupakan upaya DJP untuk meningkatkan tingkat kepatuhan wajib pajak. DJP menyiapkan tim penegakan hukum besar-besaran di tahun 2016 dan mengembalikan kepercayaan masyarakat bahwa penegakan hukum pajak akan berlaku adil tanpa pandang bulu. Direktorat Jenderal Pajak (DJP) merapatkan barisan aparat penegak hukumnya dengan mengumpulkan kurang lebih 200 penegak hukumnya dari seluruh Indonesia di Surabaya. DJP menggelar Rapat Kerja Teknis Penegakan Hukum Tahun 2015, yang berlangsung 8-12 Juni 2015. Aparat penegak hukum pajak diminta untuk tidak ragu-ragu melanjutkan penyelidikan (pemeriksaan bukti permulaan) maupun penyidikan bagi wajib pajak yang melakukan tindak pidana perpajakan. Dengan ditingkatkannya penegakan hukum akan memiliki efek jera bagi wajib pajak sehingga tingkat kepatuhan wajib pajak akan terus meningkat.

Paramartha dan Rasmini (2016) telah melakukan penelitian terdahulu yang dilakukan di Kantor Pelayanan Pajak (KPP) Gianyar, Bali pada Tahun 2015 dengan pemilihan sampel menggunakan metode slovin. Pengumpulan data dilakukan dengan menyebarkan kuesioner kepada wajib pajak badan efektif yang terdaftar di KPP Gianyar. Teknis analisisnya menggunakan analisis regresi linier berganda. Berdasarkan hasil analisis, diketahui bahwa kualitas pelayanan pengetahuan dan sanksi perpajakan berpengaruh positif signifikan terhadap kepatuhan wajib pajak badan.

Dengan adanya sita harta, gijzeling bagi Wajib Pajak yang tidak patuh dan memiliki hutang kepada DJP dan tidak ada itikad untuk menyelesaikannya memberikan efek jera terhadap Wajib Pajak. Wajib Pajak badan akan segera merespon setiap ada surat himbauan untuk menghindari sanksi pajak yang lebih berat, dengan adanya respon positif dari wajib pajak akan meningkatkan kepatuhan wajib pajak.

\section{Pemeriksaan Pajak Berpengaruh terhadap Kepatuhan Wajib Pajak ketika Dimoderasi oleh Tax Amnesty}

Berdasarkan data penelitian menunjukan pemeriksaan pajak ketika di moderasi oleh tax amnesty berpengaruh positif terhadap kepatuhan wajib pajak. Dengan mengikuti tax amnesty wajib pajak yang sedang diperiksa akan dihentikan proses pemeriksaanya, hal ini memberikan keuntungan bagi waijib pajak, dan pelaporan pajak sejak tahun 1985 sampai dengan 2015 dianggap benar dan tidak akan diperiksa kembali, artinya tahun 2016 perusahaan dimata fiskus seperti perusahaan baru yang belum ada kesalahan pajak.

Hal ini membuat penulis tertarik melakukan wawancara kepada salah seorang pengusaha kontraktor PT. Brahmakerta Adiwira, Bapak Yufizar selaku Direktur dan pemilik perusahaan tersebut, menyatakan :

"Tahun 2015 pajak saya diperiksa lima tahun ke belakang, proses pemeriksaan saya sudah masuk ke pembahasan karna satu dan lain hal saya prediksi saya harus membayar kurang lebih lima milyar, tetapi pemeriksaan saya dihentikan karena saya mengikuti tax amnesty dan saya hanya mengeluarkan 500 juta untuk membayar uang tebusan pajak saya diampuni, saya sangat berterima kasih dengan adanya tax amnesty, dan ini merupakan langkah awal bagi kami untuk lebih baih dalam melaporkan pajak."

Hal tersebut harus dimanfaatkan wajib pajak badan untuk melakukan pembenahan dalam pelapporan perpajakan, dan menjadikan langkah awal untuk melaporkan 
dan membayar tapat waktu, melakukan pembukuan dengan benar supaya kedepan jika dilakukan pemeriksaan wajib pajak sudah siap dan tidak terlalu berpengaruh terhadap akibat dari pemeriksaan tersebut.

\section{Penegakan Hukum Berpengaruh terhadap Kepatuhan Wajib Pajak jika Dimoderasi Tax Amnesty}

Berdasarkan penelitian menunjukkan adanya pengaruh penegakan hukum terhadap kepatuhan wajib pajak jika dimoderasi oleh tax amnesty. Tax amnesty dinyatakan sebagai variabel yang sempurna karena jika tidak dimasukkan dalam variabel moderasi, penegakan hukum tidak mempunyai pengaruh terhadap kepatuhan wajib pajak badan.

Ragimun (2016) dalam penelitiannya menyatakan, penerapan kebijakan pengampunan pajak diharapkan tidak hanya menghapus hak tagih atas Wajib Pajak (WP) tetapi yang lebih penting lagi dalam jangka panjang dapat memperbaiki kepatuhan WP, sehingga dapat meningkatkan penerimaan pajak di masa mendatang.

Sesuai dengan program DJP tahun 2016 sebagai tahun penegakan hukum, untuk menyukseskan program tersebut DJP memberikan pembinaan kepada wajib pajak dan membuat kebijakan pengampunan. Dengan melaporkan harta yang belum dilaporkan dengan membayar uang tebusan sesuai dengan tarif yang ditentukan yaitu 0,5\% untuk UKM, 2\% untuk tahap 1, 3\% untuk tahap 2 dan 5\% untuk tahap tiga, ataupun dengan membawa harta yang berada di luar negeri untuk dibawa ke Indonesia.

Dalam sosialisasi program tax amnesty DJP menyatakan dengan mengikuti tax amnesty maka pelaporan pajak dari tahun 1985-2015 dianggap benar dan tidak akan diperiksa kembali. Sanksi atau bunga penagihan dihapuskan bahkan hutang pajak selama belum terbit surat ketetapan akan dihapuskan sampai masa pajak 2015.

Wajib pajak yang sedang proses pemeriksaan pajak atau pemeriksaan bukti permulaan ataupun yang sedang menjalani proses pengadilan pajak selama belum adanya keputusan pengadilan pajak, jika mengikuti program pengampunan pajak proses tersebut akan dihentikan. Hal tersebut memberikan dampak positif dan mendorong wajib pajak mengikuti tax amnesty dan akan menjadi patuh.

\section{PENUTUP}

\section{Simpulan}

Hasil penelitian menunjukkan adanya dampak dari pemeriksaan pajak dan penegakan hukum terhadap kepatuhan wajib pajak badan yang dimoderasi oleh tax amnesty baik secara parsial maupun secara simultan. Artinya semakin seringnya dilakukan pemeriksaan pajak dan ditingkatkan penegakan hukum, maka tingkat kepatuhan wajib pajak akan semakin meningkat hal tersebut juga dipengaruhi karena adanya tax amnesty.

\section{Saran dan Keterbatasan}

Bagi wajib pajak diharapkan setelah melakukan tax amnesty dapat meningkatkan kepatuhan perpajakan baik dari sisi administrasi maupun pembayaran dan pelaporan dengan tepat waktu sehingga kapanpun dilakukan pemeriksaan pajak oleh fiskus wajib pajak sudah menjalankan perpajakan sesuai dengan KUP hal tersebut akan membuat wajib pajak terbebas dari masalah hukum pajak.

Keterbatasan dalam penelitian ini adalah hanya dilakukan pada wajib pajak badan yang terdaftar pada KPP Depok, dan penelitian dilakukan ketika tax amnesty belum berakhir (hanya periode satu dan dua) diharapkan untuk peneliti selanjutnya dapat melakukan penelitian untuk jangkauan yang lebih luas terhadap seluruh wajib pajak dan 
dilakukan ketika periode tax amnesty tahap tiga telah berakhir.

\section{DAFTAR PUSTAKA}

Ajzen, I. 1991. Theory of planned Behavior, Organizational Behaviour and Human Decision Processes, 50, 179-211.

Ardani N. 2010. Pengaruh Kebijakan Sunset Policy terhadap Kepatuhan Wajib Pajak, Tesis, Magister Ilmu Hukum Universitas Diponegoro, Semarang.

Aryobimo P. T., 2012. Pengaruh Persepsi Wajib Pajak tentang Kualitas Pelayanan Fiskus terhadap Kepatuhan Wajib Pajak Dengan Kondisi Keuangan Wajib Pajak dan Preferensi Risiko Sebagai Variabel Moderating (Studi Empiris terhadap Wajib Pajak Orang Pribadi di Kota Semarang). Fakultas Ekonomika Dan Bisnis Universitas Diponegoro. Skripsi Undip. Semarang.

Bandura, A. 1977. Social Learning Theory, Englewood Cliffs, Prentice Hall, New Jersey.

Brown, R.E, and Mazur, J.M. 2003. IRS,S Comperhensive Approuch to Complient Measurement.

Direktorat Jenderal Pajak. 2012. Pemeriksaan Pajak, www.pajak.go.id.

Direktorat Jenderal Pajak. 2014. Siapa yang Bertanggung Jawab terhadap Kepatuhan Pembayaran Pajak, www.pajak.go.id.

Direktorat Jenderal Pajak. 2016. Penegakan Hukum, www.pajak.go.id.

Direktorat Jenderal Pajak. 2016. Tahun Pembinaan Wajib Pajak, Laporan Tahunan.

Ghozali, Imam. 2011. Aplikasi Analisis Multivariate DenganProgram IBM SPSS 19 (edisi kelima) Semarang: Universitas Diponegoro

Harahap H.N.H. 2013. Pengaruh Pelaksanaan Pemeriksaan Pajak terhadap Tingkat Kepatuhan Wajib Pajak Badan. Fakultas Ekonomi Universitas Pasundan. Skripsi Unpas. Bandung.
Ikhsan, Budi. 2007. Kajian Terhadap FaktorFaktor yang Mempengaruhi Kepatuhan Wajib Pajak, Jurnal Akutansi Manajemen Bisnis dan Sektor Publik.

Jatmiko, AN. 2006. Pengeruh Sikap Wajib Pajak Badan pada Pelaksanaan Sanksi Denda, Pelayanan Fiskus dan Kesadaran Perpajakan terhadap Kepatuhan Wajib Pajak, Tesis Program Pasca Sarjana Universitas Diponogoro, Semarang.

Liana, Lie. 2009. Penggunaan MRA dengan SPSS untuk Menguji Pengaruh Variabel Moderating terhadap Hubungan antara Variabel Independen dan Variabel Dependen. Jurnal Teknologi Informasi.

Mandagi C, Sabijano J \& Tirayoh, V. 2014. Pengaruh Pemeriksaan Pajak Terhadap Tingkat Kepatuhan Wajib Pajak Badan Dalam Memenuhi Kewajiban Perpajakan Pada KPP Pratama Manado, Jurnal Akutansi Fakultas Ekonomi dan Bisnis Sam Ratulangi, Manado.

Mihu, G,. 2011. The Tax Audit Procedural Aspect and Consequences. Economics Management and Financial Market, Jurnal.

Modugu K.P dan Anyaduba J.O. 2014. Impact of Tax on Tax Compliance in Nigeria, International Jurnal of Business and Social Science, Nigeria.

Mukhlis,I, Utomo S.H., and Sosetyo Y. 2014. Increasing tax compliance Thourgh Strenghthening Capacity Of Education Sector For Export Oriented Smes Handicraft Field In East Java Indonesia. European Scientific Journal. ISSN.Jurnal

Paramartha dan Rasmini. 2016. Pengaruh Kualitas Pelayanan, Pengetahuan, dan Sanksi Perpajakan pada Kepatuhan Wajib Pajak Badan. E-Jurnal Akuntansi Universitas Udayana, Vol. 15.1 April (2016).

Palil M.R., and Mustapha A.F.. 2011. Factor Affering Tax Evalution and concept of tax Compliance in Asia and Europe. 
Australian Journal of Basic and Applied Sciences. Jurnal

Peraturan Menteri Keuangan No 29. 2015. Tentang Penghapusan Sanksi Administrasi dan Bunga Pajak.

Peraturan Menteri Keuangan No 81. 2013. Tentang Tata Cara Penghapusan atau Pengurangan Sanksi Administrasi Pajak.

Peraturan Menteri Keuangan No 91. 2015. Tentang Penghapusan atau Pengurangan Sanksi Pajak.

Priyitno D. 2016. SPSS Hand Book. Yogykarta

Ragimun. 2016. Analisis Implementasi Pengampunan Pajak (Tax Amnesty) di Indonesia. Jurnal Badan Kebijakan Fiskal Kemenkeu.

Rahayu S. 2009. Pengaruh Modernisasi Sistem Administrasi Perpajakan terhadap Kepatuhan Wajib Pajak (Survei atas Wajib Pajak Badan pada KPP Pratama Bandung). Jurnal Akuntansi Universitas Kristen Maranatha, Bandung.

Sekaran, U. 2010. Research Methods for Business. New York: John Wiley \& Sons

Suhendra E. S. 2010. Pengaruh Tingkat Kepatuhan Wajib Pajak Badan terhadap Peningkatan Penerimaan Pajak Penghasilan Badan. Jurnal Universitas Gunadarma, Jakarta.

Sugiono. 2011. Metode Penelitian Kuantitatif dan Kualitatif dan R\&D.

Bandung: Alfabeta

Supriyadi, E. 2014. "Perangkat lunak statistic SPSS + Amos", in Media.

Taylor, S. dan P. A. Todd. 1995. "Understanding Information

Technology Usage: A Test of Competing Models", Information System Research.

Undang-Undang Dasar 1945 Pasal 1 (3), Tentang Negara Indonesia adalah Negara Hukum.
Undang-Undang Dasar 1945 Pasal 23, Tentang Pajak dan Pemungutan Lain yang Bersifat Memaksa.

Undang-Undang RI No 6 Tahun 1983 Ketentuan Umum dan Tata Cara Perpajakan Bab III pasal 16 tentang Penetapan dan Ketetapan Pajak.

Undang-Undang RI No 6 Tahun 1983 Ketentuan Umum dan Tata Cara Perpajakan Bab VI pasal 19 tentang Penagihan Pajak.

Undang-Undang RI No 6 Tahun 1983 Ketentuan Umum dan Tata Cara Perpajakan Bab VI pasal 28 tentang Pembukuan dan Pemeriksaan.

Undang-Undang RI No 18 Tahun 2000 Tentang Perubahan atas UndangUndang Nomor 19 Tahun 1997 Tentang Penagihan Pajak dan Surat Paksa.

Undang-Undang RI No 11 Tahun 2016 tentang Pengampunan Pajak atau Tax Amnesty.

Waluyo, 2008. Perpajakan Indonesia, Salemba Empat, Jakarta.

Widjaya A. G., 2011. Studi Evaluasi Kepatuhan Wajib Pajak Sebelum dan Sesudah Reformasi Perpajakan 2008 dan Implikasinya terhadap Penerimaan pada KPP Pratama Kota Semarang di Lingkungan Kantor Wilayah Direktorat Jenderal Pajak Jawa Tengah I. Jurnal Undip, Semarang.

\section{Web:}

www.buletindepok.co. www.kemenkeu.co.id. www.konsultanstatistk.com. www.pajak.co.id. www.staistika.com. 